\title{
Remittances and Poverty
}

in Guatemala*

Richard H. Adams, Jr.

\section{Development Research Group (DECRG)}

MSN MC3-303

World Bank

1818 H Street, NW

Washington, DC 20433

Phone: 202-473-9037

E-Mail: radams@worldbank.org

World Bank Policy Research Working Paper 3418, September 2004

The Policy Research Working Paper Series disseminates the findings of work in progress to encourage the exchange of ideas about development issues. An objective of the series is to get the findings out quickly, even if the presentations are less than fully polished. The papers carry the names of the authors and should be cited accordingly. The findings, interpretations, and conclusions expressed in this paper are entirely those of the authors. They do not necessarily represent the view of the World Bank, its Executive Directors, or the countries they represent. Policy Research Working Papers are available online at http:/lecon.worldbank.org.

*I would like to thank Francois Bourguignon, Maurice Schiff, Alan Winters and participants in a World Bank Brown Bag seminar for helpful comments on an earlier draft, and Kalpana Mehra for fine research assistance. 


\begin{abstract}
$\underline{\text { Abstract }}$
This paper uses a large, nationally representative household survey to analyze the impact of internal remittances (from Guatemala) and international remittances (from the United States) on poverty in Guatemala. With only one exception, the study finds that both internal and international remittances reduce the level, depth and severity of poverty in Guatemala. However, the paper finds that remittances have a greater impact on reducing the severity as opposed to the level of poverty in Guatemala. For example, the squared poverty gap - which measures the severity of poverty - falls by 21.1 percent when internal remittances are included in household income, and by 19.8 percent when international remittances are included in such income. This is true because households in the lowest decile group receive a very large share of their total household income (expenditure) from remittances. Households in the bottom decile group receive between 50 and 60 percent of their total income (expenditure) from remittances. When these "poorest of the poor" households receive remittances, their income status changes dramatically and this in turn has a large effect on any poverty measure - like the squared poverty gap - that considers the number, distance and distribution of poor households beneath the poverty line.
\end{abstract}


In the developing world internal and international migration is often caused by individuals seeking better economic opportunities for themselves and their families. Internal migrants, coming from rural areas, stream into Third World cities seeking higher incomes in the industrial and service sectors of the economy. Responding to similar stimuli, international migrants seek improved earnings in employment located outside of their home countries.

Both internal and international migrants tend to remit or send a sizeable portion of their increased earnings to families back home. Despite the ever-increasing size of these internal and international remittances, ${ }^{1}$ very little attention has been paid to analyzing the impact of these financial transfers on poverty. Two factors seem to be responsible for this lacuna. The first is a lack of poverty data: it is quite difficult to estimate accurate and meaningful poverty levels in developing countries. The second is an absence of remittances data: few household surveys collect useful data on the size and volume of remittance transfers to households in origin communities.

As a result of these problems, there is little agreement in the literature concerning the impact of migration and remittances on poverty in the developing world. Stahl, for example, writes that "migration, particularly international migration, can be an expensive venture. Clearly it is going to be the better-off households which will be more capable of (producing migrants) (1982: 883)." Other analysts, however, maintain that the poor can and do benefit from migration and remittances. For example, Stark finds that in rural Mexico "relatively deprived" households are more likely to engage in international migration than are "better off" households (1991: 140). Similarly, Adams finds that in 
rural Egypt the number of poor households declines by 9.8 percent when household income includes international remittances, and that remittances account for 14.7 percent of the total income of poor households (1991: 73-74).

While the findings of these past studies are instructive, their conclusions are of somewhat limited utility because of small sample size and the lack of differentiation between internal migration/remittances and international migration/remittances. On the problem of sample size, Stark's findings are based on 61 households from two Mexican villages while Adams' are based on 1,000 households from three Egyptian villages. Clearly, there is a need to examine the impact of remittances on poverty using larger, more nationally representative samples. At the same time there is a continuing lack of attention to the differences between internal migration/remittances and international migration/remittances. Because of data constraints, none of the preceding studies analyze how these two different types of migration/remittances might effect poverty. Since migration has economic costs -- including travel, food, housing and job search $\operatorname{costs}^{2}$-- it is possible that internal migration/remittances might be more beneficial to the poor than international migration/remittances. However, to the best of my knowledge, no study has ever tried to examine the differential impact of these two types of migration/remittances on poverty in any single developing country. ${ }^{3}$

The purpose of this paper is to refine the debate concerning the impact of internal and international remittances on poverty by analyzing the impact of these two types of financial transfers on poverty in one specific developing country: Guatemala. Guatemala represents a good case study for examining these issues because it produces a large number of internal migrants (to urban areas) and international migrants (to the 
United States). Moreover, the presence of a new, detailed nationally-representative household survey in Guatemala makes it possible to empirically analyze the relationship between internal remittances, international remittances and poverty in that country.

The paper proceeds in five further parts. Section 1 presents the data set. Section 2 discusses the need to use predicted income functions for identifying household income excluding remittances. Section 3 then takes the results of the predicted income equations to examine the impact of internal and international remittances on poverty in Guatemala in three situations: excluding remittances, including internal remittances and including international remittances. This section finds that internal and international remittances have a greater impact on reducing the severity as opposed to the level of poverty in Guatemala. To pinpoint the reasons for this finding, Section 4 analyzes the distributional effect of internal and international remittances on different decile groups of households. Section 5 summarizes the findings.

\section{Data}

Data for the study come from a national household survey done by the Instituto Nacional de Estadistica in Guatemala during the period July to December $2000 .^{4}$ The survey included 7276 urban and rural households and was designed to be statistically representative both at the national level and for urban and rural areas. The survey was comprehensive, collecting detailed information on a wide range of topics, including income, expenditure, education, financial assets, household enterprises and remittances. ${ }^{5}$

It should, however, be emphasized that this survey was not designed as a migration or remittances survey. In fact, the survey collected very limited information on 
these topics. With respect to migration, the survey collected no information on the characteristics of the migrant: age, education or income earned away from home. On the issue of remittances, the survey only asked three questions: (1) Does your household receive remittances from family or friends?; (2) Where do these people sending remittances live?; ${ }^{6}$ and (3) How much (remittance) money did your household receive in the past 12 months? While the lack of data on migrant characteristics is unfortunate, the presence of detailed information on household income and expenditure in this survey makes it possible to use responses to these three questions to examine the impact of remittances on poverty in Guatemala.

Table 1 presents summary data from the survey. This table shows that 5665 households (77.8 percent of all households) received no remittances, 1063 households (14.6 percent) received internal remittances (from Guatemala) and 593 households (8.1 percent) received international remittances (from USA). About 88 households received both internal and international remittances and, since there is no way to separate how many of these households received internal versus international remittances, these 88 households are counted in both columns of remittance-receivers. A smaller number of households (43) received remittances from other countries (such as Central American or “other"), and are not counted as remittance-receiving households in this study.

The data in Table 1 reveal several interesting contrasts between the three groups of households, that is, those receiving no remittances, those receiving internal remittances (from Guatemala) and those receiving international remittances (from USA). On average, when compared to non-remittance households, households receiving remittances (internal or international) have more education, fewer children under age 5 
and are more likely to live in urban areas. In a broad sense these findings tend to accord with human capital theory, which suggests that educated people are more likely to migrate because educated people enjoy greater employment and income opportunities in destination areas.

However, several of the comparisons in Table 1 - specifically, those concerning number of household males over age 15 and annual per capita household income (excluding remittances) - are potentially misleading because of the following problem. Since the data in Table 1 do not include the internal or international migrant, it is not known what the number of household males or the per capita income of the households would have been if those migrants would have stayed home. In other words, with respect to household incomes (excluding remittances), the lack of statistical difference between the three groups of households in Table 1 is misleading because these incomes do not include the income contribution of the migrant had that person chosen to stay and work at home.

To overcome this methodological problem it is necessary to predict the counterfactual situation, namely, what would the incomes of all households have been in the excluding remittances situation if all migrants would have stayed and worked at home. This can be done by predicting (estimating) the per capita household incomes of all 7276 households excluding internal or international remittances. The results from these predicted income equations can then be used as a basis for evaluating the impact of remittances on poverty when internal and international remittances are included in per capita household incomes. 


\section{Predicted Income Functions}

To establish the counter-factual by predicting per capita household incomes in the excluding remittances situation, the following three-step procedure was used. First, the parameters predicting per capita household expenditure (excluding remittances) were estimated from the 5665 households which do not receive remittances. ${ }^{7}$ Second, these parameters were applied to the 1063 households which receive internal remittances (from Guatemala). Finally, the parameters were applied to the 593 households which receive international remittances (from USA). This enables us to predict per capita household expenditures in the excluding remittances situation for the three groups of households: those receiving no remittances, those receiving internal remittances and those receiving international remittances. ${ }^{8}$

Unfortunately, economic theory provides no guidance on the type of functional form that should be used in predicting per capita household expenditures. However, a linear function is sometimes used $:^{9}$

$$
\mathrm{y}_{\mathrm{i}}=\mathrm{X}_{\mathrm{i}} \alpha+\varepsilon_{\mathrm{i}}
$$

Where $\mathrm{y}_{\mathrm{i}}$ is the per capita expenditure of household $\mathrm{i}, \mathrm{X}_{\mathrm{i}}$ is a $1 \mathrm{x} \mathrm{k}$ vector of household characteristics of household $\mathrm{i}, \alpha$ is a $\mathrm{k} \mathrm{x} 1$ vector of coefficients, and $\varepsilon_{\mathrm{i}}$ is a random disturbance term.

The main econometric problem lies in selecting the variables that should go into equation (1). Specifying variables that are truly exogenous to the production of household income (expenditure) is both difficult and complex. Some variables - such as region of residence - relate to factors that are largely exogenous to the household's decision-making process. However, other variables - such as those related to household 
education - reflect a series of more-or-less internal choices made by the household at some point in time. However, since the factors that affect such endogenous choices should be fixed, it is not likely that they will seriously bias any estimates.

With these considerations in mind, it can be hypothesized that per capita household expenditure (excluding remittances) in equation (1) can be predicted as the function of the following household, education, housing, area, regional and ethnic variables:

$$
\begin{aligned}
\text { PREX }_{\mathrm{i}}=\alpha_{0} & +\alpha_{1} \text { HS }_{\mathrm{i}}+\alpha_{2} \text { MALEI5 }_{\mathrm{i}}+\alpha_{3} \text { FEMI }_{\mathrm{i}}+\alpha_{4} \text { CHILD }_{\mathrm{i}} \\
& +\alpha_{5} \text { EDPREP }_{\mathrm{i}}+\alpha_{6} \text { EDPRIM }_{\mathrm{i}}+\alpha_{7} \text { EDSEC }_{\mathrm{i}}+\alpha_{8} \text { EDUNIV }_{\mathrm{i}} \\
& +\alpha_{9} \text { WAT_PIPE }_{\mathrm{i}}+\alpha_{10} \text { WAT_WELL }_{\mathrm{i}}+\alpha_{11} \text { WAT_RIV }_{\mathrm{i}} \\
& +\alpha_{12} \text { ELEC }_{\mathrm{i}}+\alpha_{13} \text { AR }_{\mathrm{i}}+\sum_{j=1}^{7} \beta_{i j} R E G_{\mathrm{ij}}+\sum_{k=1}^{8} \lambda_{i k} \text { ETH }_{i k}+\varepsilon_{\mathrm{i}}
\end{aligned}
$$

where for the ith household, PREX is per capita household expenditure (excluding remittances), HS is household size, MALE15 is number of males in household over age 15 , FEM15 is number of females in household over age 15, CHILD5 is number of children in household under age 5, EDPREP is number of household members over age 15 with preparatory education, EDPRIM is number of household members over age 15 with primary education, EDSEC is number of household members over age 15 with secondary education, EDUNIV is number of household members over age 15 with higher (university) education, WAT_PIPE is 1 if household has piped water, zero otherwise, WAT_WELL is 1 if household has well water, zero otherwise, WAT_RIV is 1 if household has river water, zero otherwise, ELEC is 1 if household has electricity, zero otherwise, AR is area of residence ( 1 if urban, 2 if rural), REG is seven regional dummy 
variables (with metropolitan region omitted) and ETH is eight ethnic dummy variables (with indigenous omitted).

In equation (2) the dependent variable is per capita household expenditure (excluding remittances), rather than per capita income (excluding remittances). ${ }^{10}$ There are at least three reasons for using expenditure rather than income data here. First, the purpose of this paper is to estimate the impact of remittances on poverty, and most poverty economists prefer to use expenditure rather than income data to identify poverty. Since people tend to use savings to smooth fluctuations in income, poverty economists generally believe that expenditures provide a more accurate measure of an individual's welfare over time. Second, in developing country situations like Guatemala, expenditures are often easier to measure than income because of the many problems inherent in defining and measuring income for the self-employed in agriculture, who represent such a large proportion of the labor force. Third, the poverty line that will be used in this study to separate poor from non-poor households is based on expenditure rather than income data. ${ }^{11}$ In order to keep the analysis consistent, it is therefore preferable to work with expenditure data in the predicting equation.

Since the results of the predicting equation (2) depend to a large extent on the choice of regressors, it is important to discuss the reasons for including each independent variable in the model. Four household composition variables appear in equation (2). The first of these, household size, captures the impact of family size on household expenditure and is expected to be negative. The other three household composition variables relate to life-cycle factors: ${ }^{12}$ number of males over age 15 , number of females over age 15 and number of children under age 5. It is expected that the first two of these 
life-cycle variables will have a positive impact on household expenditure, and that the children variable will have a negative impact. Since previous studies have generally found that education and income are positively related, ${ }^{13}$ four education variables are included in the model. It is expected that each of these education variables will be positive and significant. Four housing characteristic variables appear in equation (2), relating to source of water and presence of electricity in the household. It is expected that each of these variables will be positively signed. In developing countries like Guatemala, average household expenditures are generally larger in urban than rural areas. For this reason, an area variable ( 1 if urban, 2 if rural) is included in the model; this variable is expected to have a negative sign. Finally, since region of residence and ethnicity of the household are likely to affect the level of household expenditures, seven regional and eight ethnic dummies are included in equation (2). Since the reference (omitted) category for these regional and ethnicity variables is associated with high levels of household expenditures, it is expected that these dummy variables will generally be negative.

Table 2 reports the results obtained from using equation (2) to predict per capita household expenditure (excluding remittances). Except for the two variables measuring the number of household males and females over age 15, all of the coefficients have the expected signs. The overwhelming majority of variables (10 of 13 variables ) are also highly significant at the 5 percent level. The results from this table can be used to predict per capita household expenditure in the excluding remittances situation for the three groups of households: (1) those receiving no remittances; (2) those receiving internal remittances (from Guatemala); and (3) those receiving international remittances (from USA). 
Once household expenditures have been predicted for the three groups of households in the excluding remittances situation, household expenditures in the including remittances situation can be calculated for those households receiving internal or international remittances. This can be done by using the following two steps: first, for those households receiving internal or international remittances, setting to zero the predicted income contribution of the migrant as estimated from equation (2); and second, adding in the actual amounts of internal or international remittances received by households receiving these types of transfers. For households receiving remittances, internal and international remittances average 1,431.4 and 2,259.2 quetzals per capita per year, respectively. ${ }^{14}$

Table 3 summarizes our efforts to predict per capita household expenditure for the three groups of households in the two situations: excluding and including remittances. Three key findings emerge from this table. First, contrary to the "naïve" results recorded in Table 1, when predicted equations are used to estimate the level of household expenditures, households receiving remittances are richer - in a statistical sense -- than those households not receiving remittances. In the excluding remittances situation, the mean level of expenditures for households receiving internal and international remittances is 24.4 and 16.4 percent higher, respectively, than that for households not receiving remittances. The reasons for this has already been noted. Migration, especially international migration, can be a costly endeavor and thus represents a more viable option for households with more income (expenditure). However, the second finding from Table 3 tends to bring a cautionary note to the preceding. While migration may have its costs, it is rather paradoxical to note that in the 
excluding remittances situation, households receiving internal remittances (from Guatemala) have higher mean incomes (expenditures) than do households receiving international remittances (from USA). Since internal migration should generally be less expensive than international migration, this outcome is unexpected. Perhaps the best explanation for this paradoxical outcome is that while migration may have its costs, the economic costs of migration are not the only factor "explaining" the willingness of people to go work in another place. The final finding in Table 3 is quite expected, namely that remittances really increase the level of household expenditure. In the including remittances situation, the average level of expenditures for households receiving internal and international remittances is 43.7 and 46.9 percent higher, respectively, than that for households not receiving remittances. Remittances - from within a country or from abroad - significantly boost the income (expenditure) of those households that are able to produce a migrant.

\section{Remittances and Poverty}

Now that per capita household expenditures have been predicted in the two situations - excluding and including remittances - for the three groups of households, it is possible to examine the impact of these financial transfers on poverty in Guatemala. This is done in Table 4.

Table 4 is based on the World Bank poverty line for Guatemala in the year 2000 of 4319 quetzels/person/year. This poverty line is defined as the level of per capita expenditures needed to meet the costs of attaining minimum food requirements of 2172 kilocalories/person/day. To this food line the costs of meeting minimum nonfood 
expenditures are also added. The result is a national poverty line - including both food and nonfood costs - for Guatemala in the year 2000. ${ }^{15}$

Table 4 reports three different poverty measures based on this national poverty line. The first, the poverty headcount, measures the percent of the population living beneath the poverty line. However, this headcount index ignores the "depth of poverty," that is, the amount by which the average expenditure of the poor fall short of the poverty line. The table therefore also reports the poverty gap index, which measures in percentage terms how far the average expenditures of the poor fall short of the national poverty line. For instance, a poverty gap of 10 percent means that the average expenditure of the poor is 90 percent of the poverty line. The third poverty measure -the squared poverty gap index - indicates the severity of poverty. The squared poverty gap index possesses useful analytical properties, because it is sensitive to changes in distribution among the poor. In other words, while a transfer of expenditures from a poor person to a poorer person will not change the headcount index or the poverty gap index, it will decrease the squared poverty gap index.

Columns (1-4) of Table 4 report the results for the different poverty measures. Column (1) reports results in the excluding remittances situation, column (2) reports results when only internal remittances are included in household expenditure, and column (3) reports the results when only international remittances are included. Column (4) reports results when both internal and international remittances are included in household expenditure.

With only one exception, the various poverty measures in Table 4 show that the inclusion of remittances - either internal or international - in household expenditure 
reduces the level, depth and severity of poverty in Guatemala. ${ }^{16}$ However, the size of the poverty reduction depends very much on how poverty is measured. According to the poverty headcount measure, including internal remittances in household expenditure reduces the level of poverty by only 0.6 percent and including international remittances in such expenditure actually increases the level of poverty by 1.1 percent. However, poverty is reduced much more when measured by indicators focusing on the depth and severity of poverty, such as the poverty gap and squared poverty gap. For example, the squared poverty gap measure shows that including internal or international remittances in household expenditure reduces poverty by 21.1 or 19.8 percent, respectively. In other words, including remittances - either internal or international -- in household expenditure has a greater impact on reducing the severity of poverty in Guatemala than it does on reducing the proportion of people living in poverty.

Columns (1-4) of Table 4 reveal that the inclusion of internal or international remittances in household expenditure has little impact on income inequality, as measured by the Gini coefficient. ${ }^{17}$ With the receipt of either internal or international remittances, inequality remains relatively stable with a Gini coefficient of about 0.49 . This means that most of the poverty-reducing effect of remittances in Guatemala comes from increases in mean household income (expenditure) rather than from any progressive change in income inequality caused by these income flows.

Since the Gini coefficient aggregates the impact of remittances on inequality to a single number, it often conceals as much as it reveals. To gain a more detailed view of the effect of these resource flows on inequality it is useful to draw Lorenz concentration curves for the three situations - excluding remittances, including internal remittances and 
including international remittances -- and compare these curves to the 45-degree line of perfect equality. This is done in Figure 1, which shows that the three remittance curves for excluding remittances, including internal remittances and including international remittances -- cross. This means that none of the remittance curves is more egalitarian than the other two. The distribution corresponding to excluding remittances is more equal among the poorest and the middle part of the distribution, but the distributions corresponding to including internal and international remittances are more equal among the richest.

With respect to poverty, Table 4 shows that that the receipt of internal remittances has a slightly greater impact on poverty than the receipt of international remittances. For instance, all three poverty measures show that the extent of poverty reduction is greater when internal remittances are included in household expenditure, as opposed to when international remittances are included. While the poverty-reducing differences between these two types of remittance are small, this finding is as expected. Since the costs of internal migration are probably lower than those for international migration, internal migration and remittances should (in theory) have more of a beneficial impact on the poor. The data in Table 4 suggest that this is largely true in Guatemala. 


\section{Remittances, Poverty and Income Distribution}

One of the key findings in Table 4 is that remittances - either internal or international - have a greater impact on reducing the severity as opposed to the level of poverty in Guatemala. One way to explore the reasons for this finding is to examine what kinds of income (expenditure) groups of households receive internal and international remittances. If, for example, households at the bottom of the income distribution are receiving more remittances than households nearer the poverty line or if these "very poor" households are receiving a greater proportion of their income from remittances than other types of households, then remittances will have a greater impact on the severity of poverty as opposed to the level of poverty.

To pursue this analysis, Table 5 ranks all the households into decile groups on the basis of predicted per capita household expenditure (excluding remittances). Columns (1) and (3) then show the proportion of total households receiving internal and international remittances, respectively, in each decile group. For those households receiving remittances, columns (2) and (4) show the percent of total per capita household expenditure (including remittances) coming from internal or international remittances for each decile group. ${ }^{18}$

As expected, columns (1) and (3) in Table 5 show that rich households specifically, those in the eight and ninth deciles of the expenditure distribution - account for the largest share of remittance-receivers. Households in these two deciles account for between 15 and 22 percent of all remittance-receivers for both internal and international remittances. However, a surprisingly large share of households receiving remittances 8.7 percent for internal remittances and 9.0 percent for international remittances - are 
found in the lowest decile group. Moreover, columns (2) and (3) in Table 5 show that households in the bottom decile group receive a huge share of their total per capita household expenditure (income) from remittances. On average, households in the lowest decile group receiving internal remittances receive 50 percent of their total household income from remittances; households in the bottom group receiving international remittances receive 60 percent of their total household income from this source. This finding serves to explain why remittances have more of an impact on reducing the severity rather than the level of poverty in Guatemala. When households in the lowest decile group - the "poorest of the poor" -- receive internal or international remittances their income (expenditure) increases between 50 and 60 percent. This in turn has a huge effect on any poverty measure - like the squared poverty gap - which considers the number, distance and distribution of poor households beneath the poverty line. By contrast, Table 5 shows that relatively few households near the poverty line (roughly the fifth decile group) either receive remittances or that remittances account for a very large share of their total per capita household expenditure (income). As a result, the poverty headcount measure does not decline much with the inclusion of internal or international remittances in household expenditure (income).

The question then arises: Are there any particular socio-economic characteristics of households in the lowest decile group which enable them to receive such a large share of internal or international remittances? In other words, what distinguishes households in the bottom decile group from other types of remittance-receiving households?

One means of addressing this question is to estimate a logit model on the determinants of being - or not being - in the lowest decile group and receiving internal 
or international remittances. Such a logit model can be estimated in a manner similar to equation (2):

$$
\begin{aligned}
\text { REMPOR , } & \text { REMNTPOR }=\alpha_{0}+\alpha_{1} \text { HS }_{\mathrm{i}}+\alpha_{2} \text { MALEI }_{\mathrm{i}}+\alpha_{3} \text { FEMI }_{\mathrm{i}} \\
& +\alpha_{4} \text { CHILD }_{\mathrm{i}}+\alpha_{5} \text { EDPREP }_{\mathrm{i}}+\alpha_{6} \text { EDPRIM }_{\mathrm{i}}+\alpha_{7} \text { EDSEC }_{\mathrm{i}} \\
& +\alpha_{8} \text { EDUNIV }_{\mathrm{i}}+\alpha_{9} \text { WAT_PIPE }_{\mathrm{i}}+\alpha_{10} \text { WAT_WELL }_{\mathrm{i}} \\
& +\alpha_{11} \text { WAT_RIV }_{\mathrm{i}}+\alpha_{12} \text { ELEC }_{\mathrm{i}}+\alpha_{13} \mathrm{AR}_{\mathrm{i}}+\sum_{j=1}^{7} \beta_{i j} \text { REG }_{\mathrm{ij}} \\
& +\sum_{k=1}^{8} \lambda_{i k} \text { ETH }_{i k}+\varepsilon_{\mathrm{i}}
\end{aligned}
$$

Where REMPOR is one if the household receives remittances (internal or international) and is in the lowest decile group (excluding remittances), and zero otherwise; REMNTPOR is one if household receives remittances (internal or international) and is not in the lowest decile group (excluding remittances), and zero otherwise; and all other variables are defined as in equation (2) above.

Tables 6 and 7 present results of the logit model for households receiving internal (Table 6) and international remittances (Table 7). The model is estimated only for those households which receive remittances; non-remittance receiving households are excluded from the analysis. In each table column (1) shows the results when the household is in the lowest decile group and receives remittances, and column (2) shows the results when the household is not in the lowest decile group and receives remittances.

Table 6 shows the logit model results for households receiving internal remittances. The findings are rather disappointing. Only two of the variables household size and area (1=urban, $2=$ rural $)$ - are statistically different between columns (1) and (2). In other words, when compared to other internal-remittance receiving 
households, households in the lowest decile group are more likely to be larger in size and more likely to come from rural areas. The finding about more household members might be expected, but the finding about rural residence might not be. However, in Guatemala households receiving internal remittances and living in rural areas are much poorer than their counterparts in urban areas. In the excluding remittances situation, rural households receiving internal remittances average 5168 quetzals/person/year, while their urban counterparts average 11,621 quetzals/person/year..

Table 7, which shows the logit results for households receiving international remittances, is also disappointing. ${ }^{19}$ Again, only two of the variables - number of females in household over age 15 and number of household members over age 15 with secondary education - are statistically different between columns (1) and (2). The results for the education variable suggest that when compared to other international-remittance receiving households, households in the lowest decile group are less likely to have secondary education. However, this finding is not a very strong one because none of the other education variables in column (1) are negative and statistically significant.

\section{5. $\underline{\text { Conclusion }}$}

This paper has used a large, nationally representative household survey $(\mathrm{N}=7276$ households) and predicted income functions to analyze the impact of internal remittances (from Guatemala) and international remittances (from the United States) on poverty in Guatemala. Four key findings emerge.

First, both internal and international remittances represent important components of household income in Guatemala. While less than 25 percent of all households in 
Guatemala receive remittances, for those households receiving remittances these income flows are very important. Remittances account for 13.4 percent of total per capita household income (expenditure) for households receiving internal remittances, and remittances represent 20.8 percent of household income for households receiving international remittances.

Second, with only one exception, both types of remittances reduce the level, depth and severity of poverty in Guatemala. However, the size of the poverty reduction depends very much on how poverty is measured. According to the poverty headcount measure, including internal remittances in household expenditure reduces the level of poverty by only 0.6 percent and including international remittances in such expenditure actually increases the level of poverty by 1.1 percent. However, poverty is reduced much more when measured by indicators focusing on the depth and severity of poverty, such as the poverty gap and squared poverty gap. For example, the squared poverty gap measure shows that including internal or international remittances in household expenditure reduces poverty by 21.1 or 19.8 percent, respectively.

Third, remittances have a greater impact on reducing the severity rather than the level of poverty in Guatemala because of the kinds of income (expenditure) groups receiving remittances. Using predicted income functions to rank all households into decile groups on the basis of per capita expenditure (excluding remittances) shows that households in the bottom decile group receive a very large share of their total household expenditure (income) from remittances. On average, households in the lowest decile group receiving internal remittances receive 50 percent of their total household income from remittances and households in the bottom decile receiving international remittances 
receive 60 percent of their total income from this source. This explains why remittances have more of an impact on reducing the severity rather than the level of poverty in Guatemala. When households in the lowest decile group receive remittances their income (expenditure) status changes dramatically and this in turn has a huge effect on any poverty measure - like the squared poverty gap - which considers the number, distance and distribution of poor households beneath the poverty line. By contrast, remittances do not account for a very large share of total income for those households located near the poverty line (roughly the fifth decile group). As a result, the poverty headcount measure does not decline as much as the squared poverty gap with the inclusion of remittances in household expenditure (income).

Finally, this study shows that including internal or international remittances in household income (expenditure) has little impact on income inequality. This means that most of the poverty-reducing effect of internal or international remittances in Guatemala comes from increases in mean per capita household income rather than from any progressive change in income inequality caused by these income flows. With the receipt of remittances in Guatemala, income inequality remains relatively stable (Gini coefficient $\sim 0.49$ ), and so the main impact of these transfers on poverty is the increase that these income flows have upon the level of per capita household income (expenditure). 
Table 1. Summary Data on Non-Remittance and Remittance-Receiving Households, Guatemala, 2000

\begin{tabular}{|c|c|c|c|c|c|}
\hline Variable & $\begin{array}{l}\text { Receive no } \\
\text { remittances }\end{array}$ & $\begin{array}{l}\text { Receive internal } \\
\text { remittances (from } \\
\text { Guatemala) }\end{array}$ & $\begin{array}{c}\text { Receive } \\
\text { international } \\
\text { remittances (from } \\
\text { USA) } \\
\end{array}$ & $\begin{array}{c}\text { t-test (No } \\
\text { remittances vs. } \\
\text { internal } \\
\text { remittances) } \\
\end{array}$ & $\begin{array}{c}\text { t-test (No } \\
\text { remittances vs. } \\
\text { international } \\
\text { remittances }\end{array}$ \\
\hline Mean household size & $\begin{array}{c}5.32 \\
(2.46)\end{array}$ & $\begin{array}{c}4.74 \\
(2.69)\end{array}$ & $\begin{array}{c}5.18 \\
(2.68)\end{array}$ & $6.50^{* *}$ & 0.52 \\
\hline $\begin{array}{l}\text { Mean number of males in } \\
\text { household over age } 15\end{array}$ & $\begin{array}{c}1.35 \\
(0.84)\end{array}$ & $\begin{array}{c}1.19 \\
(0.98)\end{array}$ & $\begin{array}{c}1.21 \\
(1.00)\end{array}$ & $6.67 * *$ & $3.52^{* *}$ \\
\hline $\begin{array}{l}\text { Mean number of children } \\
\text { in household under age } 5\end{array}$ & $\begin{array}{c}0.88 \\
(0.96) \\
\end{array}$ & $\begin{array}{c}0.62 \\
(0.89)\end{array}$ & $\begin{array}{c}0.69 \\
(0.96) \\
\end{array}$ & $8.14 * *$ & $5.49 * *$ \\
\hline $\begin{array}{l}\text { Mean number of } \\
\text { household members over } \\
\text { age } 15 \text { with secondary } \\
\text { education }\end{array}$ & $\begin{array}{c}0.94 \\
(1.07)\end{array}$ & $\begin{array}{c}1.01 \\
(1.19)\end{array}$ & $\begin{array}{c}1.09 \\
(1.17)\end{array}$ & $-2.07 *$ & $-4.17 * *$ \\
\hline $\begin{array}{l}\text { Household has electricity } \\
(1=y e s, \text { otherwise zero) }\end{array}$ & $\begin{array}{c}0.71 \\
(0.45)\end{array}$ & $\begin{array}{c}0.78 \\
(0.41)\end{array}$ & $\begin{array}{c}0.83 \\
(0.38)\end{array}$ & $-5.44 * *$ & $-8.54 * *$ \\
\hline Area $(1=$ urban, $2=$ rural $)$ & $\begin{array}{l}1.58 \\
(0.49) \\
\end{array}$ & $\begin{array}{r}1.49 \\
(0.50) \\
\end{array}$ & $\begin{array}{c}1.52 \\
(0.49) \\
\end{array}$ & $6.51 * *$ & $5.02 * *$ \\
\hline $\begin{array}{l}\text { Mean annual per capita } \\
\text { income (excluding } \\
\text { remittances) in } \\
\text { Guatemalan quetzals }\end{array}$ & $\begin{array}{r}6,798.98 \\
(14,021.5)\end{array}$ & $\begin{array}{c}6,523.24 \\
(8,351.7)\end{array}$ & $\begin{array}{r}7,042.01 \\
(13,307.4)\end{array}$ & 0.45 & -0.12 \\
\hline $\mathrm{N}$ & 5,665 & 1,063 & 593 & & \\
\hline
\end{tabular}

Notes: $\quad \mathrm{N}=7,276$ households; 88 households receive both internal remittances (from Guatemala) and international remittances (from USA). All values are weighted; standard deviations are in parentheses.

In 2000, 1 Guatemalan quetzal $=$ US\$0.128.

Source: Guatemala 2000 ENCOVI Survey, Instituto Nacional de Estadistica.

*Significant at the 0.05 level.

**Significant at the 0.01 level. 
Table 2. Regression to Estimate Predicted Per Capita Household Expenditure (Excluding Remittances)

\section{Variable}

Regression

coefficient t-ratio

\begin{tabular}{|c|c|c|}
\hline Variable & $\begin{array}{l}\text { Regression } \\
\text { coefficient }\end{array}$ & t-ratio \\
\hline \multicolumn{3}{|l|}{ Household Composition } \\
\hline Household size & -735.52 & $-12.71 * *$ \\
\hline Number of males over age 15 & -618.98 & $-4.17 * *$ \\
\hline Number of females over age 15 & -558.93 & $-3.80 * *$ \\
\hline Number of children under age 5 & -579.21 & $-4.94 * *$ \\
\hline \multicolumn{3}{|l|}{ Education (excluded no education) } \\
\hline $\begin{array}{l}\text { Number of members over age } 15 \text { with } \\
\text { preparatory education }\end{array}$ & -342.82 & -0.80 \\
\hline $\begin{array}{l}\text { Number of members over age } 15 \text { with } \\
\text { primary education }\end{array}$ & 27.38 & 0.25 \\
\hline $\begin{array}{l}\text { Number of members over age } 15 \text { with } \\
\text { secondary education }\end{array}$ & 1169.15 & $8.93^{* *}$ \\
\hline $\begin{array}{l}\text { Number of members over age } 15 \text { with } \\
\text { university education }\end{array}$ & 5770.25 & $27.96^{* *}$ \\
\hline \multicolumn{3}{|l|}{$\begin{array}{l}\text { Housing Characteristics } \\
\text { otherwise zero) }\end{array}$} \\
\hline House has piped water & 1384.18 & $3.51 * *$ \\
\hline House has well water & 808.54 & 1.91 \\
\hline House has river water & 1122.55 & $2.28^{*}$ \\
\hline House has electricity & 1129.74 & $4.64 * *$ \\
\hline \multicolumn{3}{|l|}{ Area } \\
\hline Area $(1=$ urban, $2=$ rural $)$ & -1299.78 & $-5.88 * *$ \\
\hline Constant & $17,101.28$ & $28.08 * *$ \\
\hline \multicolumn{3}{|l|}{ Adj. $R^{2}=0.447$} \\
\hline F-statistic $=164.51$ & & \\
\hline
\end{tabular}

Notes: Regression is based on those 5,665 households which receive no remittances. The parameters are used to predict per capita household expenditures (excluding remittances) for households which receive internal remittances (from Guatemala) or international remittances (from USA). Seven regional and eight ethnic dummy variables are included in the equation, but not reported in the table.

*Significant at the 0.05 level. **Significant at the 0.01 level. 
Table 3. Predicted Per Capita Expenditures for Non-Remittance and Remittance-Receiving Households, Guatemala, 2000

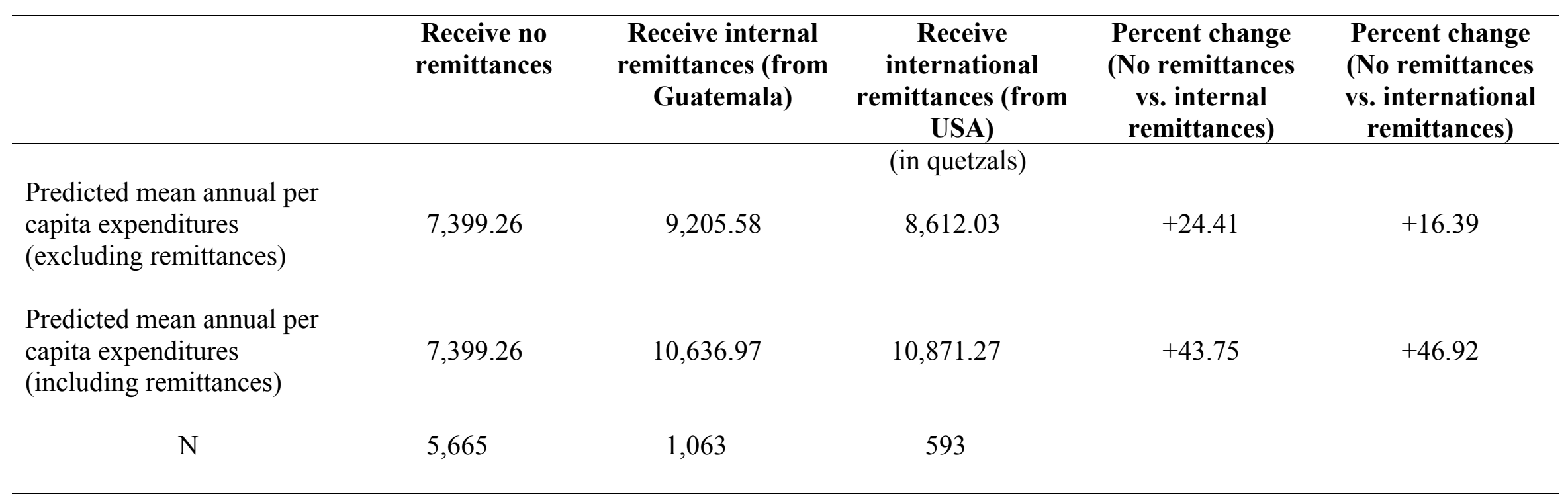

Notes: $\quad \mathrm{N}=7,276$ households; 88 households receive both internal remittances (from Guatemala) and international remittances (from USA). All values are predicted from equation (2); see text. All values are weighted.

In 2000, 1 Guatemalan quetzal $=$ US $\$ 0.128$.

Source: Calculated from Guatemala 2000 ENCOVI Survey. 
Table 4. Effect of Remittances on Poverty for Non-Remittance and Remittance-Receiving Households, Guatemala, 2000

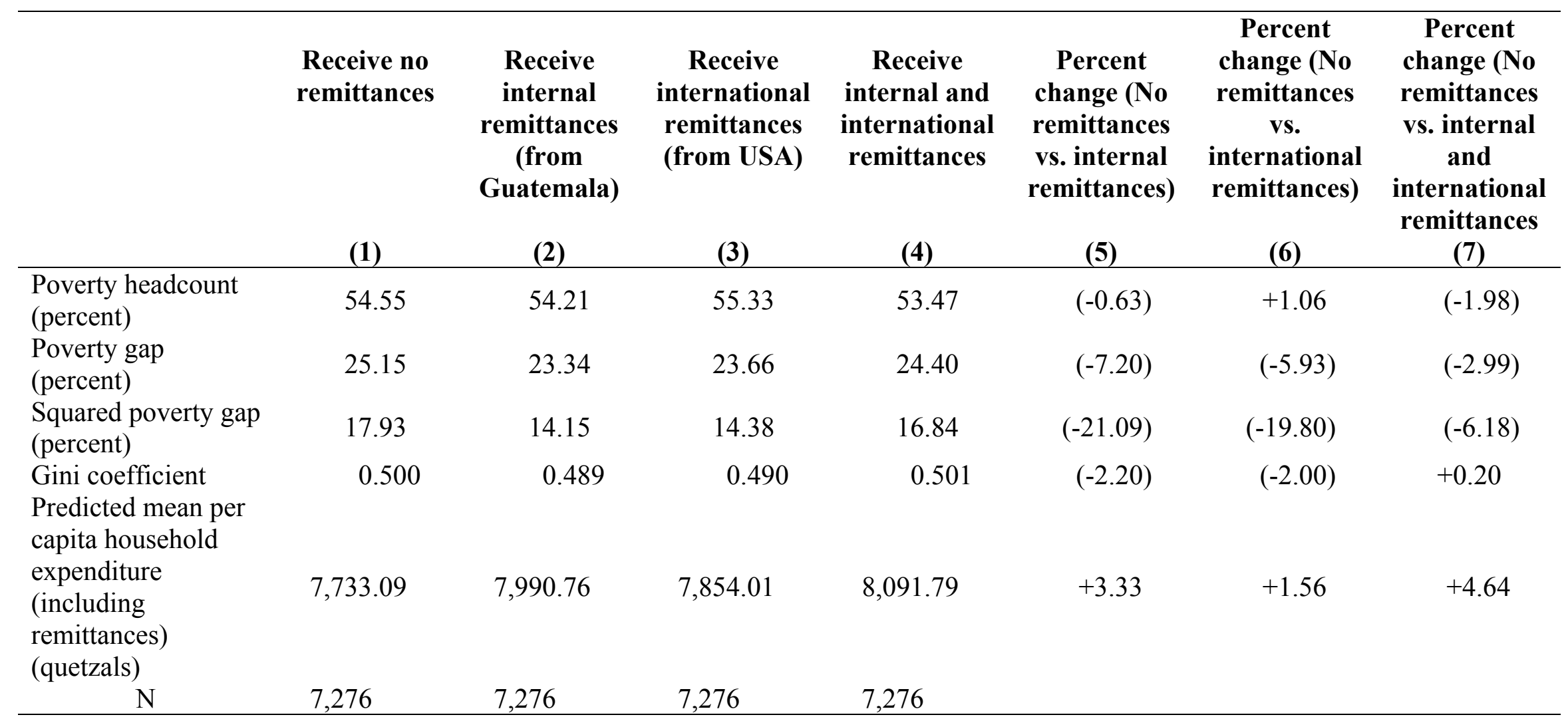

Notes: Column (1) uses predicted income equations to measure the situation excluding remittances for all 7,276 households. Column (2) measures the situation for all households when only internal remittances (from Guatemala) are included in predicted household expenditure. Column (3) measures the situation for all households when only international remittances (from USA) are included in predicted household expenditure. Column (4) measures the situation for all households when both internal and international remittances are included in predicted household expenditure. Poverty calculations made using $2000 \mathrm{World}$ Bank poverty line of 4,319 quetzals/ person/ year. For predicted income equation, see equation (2) and text. All values are weighted.

In 2000,1 Guatemalan quetzal $=$ US $\$ 0.128$.

Source: Calculated from Guatemala 2000 ENCOVI Survey 
Table 5. Distribution of Remittance-Receiving Households by Decile Group, Ranked by Predicted Per Capita Household Expenditure, Excluding Remittances

\begin{tabular}{|c|c|c|c|c|}
\hline Rank & $\begin{array}{l}\text { Households } \\
\text { receiving } \\
\text { internal } \\
\text { remittances } \\
\text { (from } \\
\text { Guatemala) }\end{array}$ & $\begin{array}{c}\text { Internal } \\
\text { remittances as } \\
\text { percent of total } \\
\text { per capita } \\
\text { household } \\
\text { expenditure } \\
\text { (including } \\
\text { remittances) }\end{array}$ & $\begin{array}{l}\text { Households } \\
\text { receiving } \\
\text { international } \\
\text { remittances } \\
\text { (from USA) }\end{array}$ & $\begin{array}{c}\text { International } \\
\text { remittances as } \\
\text { percent of total } \\
\text { per capita } \\
\text { household } \\
\text { expenditure } \\
\text { (including } \\
\text { remittances) }\end{array}$ \\
\hline & (1) & (2) & (3) & (4) \\
\hline (decile) & (percent) & (percent) & (percent) & (percent) \\
\hline Lowest 10 & 8.7 & 50.1 & 9.0 & 60.1 \\
\hline Second 10 & 2.1 & 8.9 & 2.7 & 34.5 \\
\hline Third 10 & 3.1 & 14.8 & 3.5 & 39.3 \\
\hline Fourth 10 & 4.7 & 12.3 & 6.0 & 24.6 \\
\hline Fifth 10 & 5.8 & 11.2 & 8.1 & 23.0 \\
\hline Sixth 10 & 10.1 & 8.1 & 10.0 & 24.1 \\
\hline Seventh 10 & 13.4 & 9.6 & 15.4 & 22.8 \\
\hline Eighth 10 & 18.2 & 13.0 & 15.7 & 21.3 \\
\hline Ninth 10 & 22.5 & 10.2 & 18.7 & 14.8 \\
\hline \multirow[t]{2}{*}{ Top 10} & 11.4 & 19.6 & 10.9 & 19.1 \\
\hline & 100.0 & & 100.0 & \\
\hline
\end{tabular}

Notes: Households ranked into decile groups on the basis of predicted per capita household expenditure (excluding remittances). For those households receiving internal remittances (from Guatemala), column (2) shows the percent of total per capita household expenditure (including remittances) coming from internal remittances. For those households receiving international remittances (from USA), column (4) shows the percent of total per capita household expenditure (including remittances) coming from international remittances. See equation (2) and text for predicted income equation.

Source: Calculated from Guatemala 2000 ENCOVI Survey. 
Table 6. Logit Analysis of Characteristics of Households Receiving Internal Remittances (from Guatemala)

\begin{tabular}{|c|c|c|}
\hline \multirow[b]{2}{*}{ Variable } & \multicolumn{2}{|c|}{ Households receiving internal remittances and: } \\
\hline & $\begin{array}{l}\text { In lowest decile group } \\
\text { (1) }\end{array}$ & $\begin{array}{c}\text { Not in lowest decile group } \\
\text { (2) }\end{array}$ \\
\hline \multicolumn{3}{|l|}{ Household Composition } \\
\hline$\overline{\text { Household size }}$ & $\begin{array}{c}0.766 \\
(7.02)^{* *}\end{array}$ & $\begin{array}{l}-0.268 \\
(-6.77)^{* *}\end{array}$ \\
\hline Number of males over age 15 & $\begin{array}{c}0.730 \\
(3.48)^{* *}\end{array}$ & $\begin{array}{l}0.037 \\
(0.42)\end{array}$ \\
\hline Number of females over age 15 & $\begin{array}{l}0.286 \\
(1.38)\end{array}$ & $\begin{array}{l}0.145 \\
(1.56)\end{array}$ \\
\hline Number of children over age 5 & $\begin{array}{l}0.007 \\
(0.04)\end{array}$ & $\begin{array}{l}0.041 \\
(0.50)\end{array}$ \\
\hline \multicolumn{3}{|l|}{ Education (excluded no education) } \\
\hline $\begin{array}{l}\text { Number of members over age } 15 \text { with } \\
\text { preparatory education }\end{array}$ & $\begin{array}{l}-0.045 \\
(-0.46)\end{array}$ & $\begin{array}{l}-0.705 \\
(-2.08)^{*}\end{array}$ \\
\hline $\begin{array}{l}\text { Number of members over age } 15 \text { with } \\
\text { primary education }\end{array}$ & $\begin{array}{c}-0.343 \\
(-2.09)^{*}\end{array}$ & $\begin{array}{l}0.006 \\
(0.09)\end{array}$ \\
\hline $\begin{array}{l}\text { Number of members over age } 15 \text { with } \\
\text { secondary education }\end{array}$ & $\begin{array}{c}-1.270 \\
(-3.48)^{* *}\end{array}$ & $\begin{array}{l}0.030 \\
(0.39)\end{array}$ \\
\hline $\begin{array}{l}\text { Number of members over age } 15 \text { with } \\
\text { university education }\end{array}$ & --- & $\begin{array}{c}0.469 \\
(3.15)^{* *}\end{array}$ \\
\hline \multicolumn{3}{|l|}{$\begin{array}{l}\text { Housing } \underline{\text { Characteristics }} \underline{(1=y e s,} \\
\text { otherwise zero })\end{array}$} \\
\hline House has piped water & $\begin{array}{c}-2.245 \\
(-3.04)^{* *}\end{array}$ & $\begin{array}{l}0.007 \\
(0.02)\end{array}$ \\
\hline House has well water & $\begin{array}{l}-1.908 \\
(-2.49)^{*}\end{array}$ & $\begin{array}{l}-0.263 \\
(-0.78)\end{array}$ \\
\hline House has river water & $\begin{array}{l}-1.530 \\
(-1.80)\end{array}$ & $\begin{array}{l}-0.147 \\
(-0.35)\end{array}$ \\
\hline House has electricity & $\begin{array}{c}-1.384 \\
(-3.57)^{* *}\end{array}$ & $\begin{array}{c}-0.567 \\
(-3.31)^{* *}\end{array}$ \\
\hline$\underline{\text { Area }}$ & & \\
\hline Area $(1=$ urban, $2=$ rural $)$ & $\begin{array}{c}1.584 \\
(2.90)^{* *}\end{array}$ & $\begin{array}{l}-0.285 \\
(-1.95)^{*}\end{array}$ \\
\hline Constant & $\begin{array}{l}-29.037 \\
(-8.70)^{* *}\end{array}$ & $\begin{array}{c}2.484 \\
(5.84)^{* *}\end{array}$ \\
\hline Log likelihood & -137.45 & -920.04 \\
\hline $\begin{array}{ll}* & \text { Significant at the } 0.05 \text { level. } \\
* * & \text { Significant at the } 0.01 \text { level. }\end{array}$ & & \\
\hline
\end{tabular}

Notes: $\mathrm{N}=1568$ households. Numbers in parentheses are t-statistics (two-tailed). In column (1) the dependent variable is 1 if household receives internal remittances and is in the lowest decile group (excluding remittances), and zero otherwise. In column (2), the dependent variable is 1 if household receives internal remittances and is not in the lowest decile group (excluding remittances), and zero otherwise. Seven regional and eight ethnic dummy variables are included in the equation, but not reported in the table. 
Table 7. Logit Analysis of Characteristics of Households Receiving International Remittances (from USA)

\begin{tabular}{|c|c|c|}
\hline \multirow[b]{2}{*}{ Variable } & \multicolumn{2}{|c|}{ Households receiving international remittances and: } \\
\hline & $\begin{array}{l}\text { In lowest decile group } \\
\text { (1) }\end{array}$ & $\begin{array}{c}\text { Not in lowest decile group } \\
\text { (2) }\end{array}$ \\
\hline \multicolumn{3}{|l|}{ Household Composition } \\
\hline$\overline{\text { Household size }} \overline{\text { size }}$ & $\begin{array}{c}0.574 \\
(4.18)^{* *}\end{array}$ & $\begin{array}{l}0.081 \\
(2.05)^{*}\end{array}$ \\
\hline Number of males over age 15 & $\begin{array}{l}0.185 \\
(0.64)\end{array}$ & $\begin{array}{c}-0.282 \\
(-3.06)^{* *}\end{array}$ \\
\hline Number of females over age 15 & $\begin{array}{l}0.700 \\
(2.48)^{*}\end{array}$ & $\begin{array}{c}-0.311 \\
(-3.18)^{* *}\end{array}$ \\
\hline Number of children over age 5 & $\begin{array}{l}0.304 \\
(1.29)\end{array}$ & $\begin{array}{c}-0.349 \\
(-3.98) * *\end{array}$ \\
\hline \multicolumn{3}{|l|}{ Education (excluded no education) } \\
\hline $\begin{array}{l}\text { Number of members over age } 15 \text { with } \\
\text { preparatory education }\end{array}$ & $\begin{array}{l}0.404 \\
(0.48)\end{array}$ & $\begin{array}{l}0.735 \\
(2.33)^{*}\end{array}$ \\
\hline $\begin{array}{l}\text { Number of members over age } 15 \text { with } \\
\text { primary education }\end{array}$ & $\begin{array}{l}0.019 \\
(0.09)\end{array}$ & $\begin{array}{c}0.139 \\
(1.78)\end{array}$ \\
\hline $\begin{array}{l}\text { Number of members over age } 15 \text { with } \\
\text { secondary education }\end{array}$ & $\begin{array}{l}-1.221 \\
(-2.38)^{*}\end{array}$ & $\begin{array}{c}0.373 \\
(4.59)^{* *}\end{array}$ \\
\hline $\begin{array}{l}\text { Number of members over age } 15 \text { with } \\
\text { university education }\end{array}$ & --- & $\begin{array}{l}0.045 \\
(0.35)\end{array}$ \\
\hline \multicolumn{3}{|l|}{$\underline{\text { Housing Characteristics }} \underline{\text { otherwise }} \underline{(1=\text { yero })}$} \\
\hline$\overline{\text { House has piped water }}$ & $\begin{array}{l}16.799 \\
(0.01)\end{array}$ & $\begin{array}{l}0.006 \\
(0.02)\end{array}$ \\
\hline House has well water & $\begin{array}{l}17.600 \\
(0.01)\end{array}$ & $\begin{array}{l}0.136 \\
(0.40)\end{array}$ \\
\hline House has river water & $\begin{array}{l}17.237 \\
(0.01)\end{array}$ & $\begin{array}{l}-0.375 \\
(-0.80)\end{array}$ \\
\hline House has electricity & $\begin{array}{l}-0.116 \\
(0.25)\end{array}$ & $\begin{array}{c}0.931 \\
(4.98)^{* *}\end{array}$ \\
\hline \multicolumn{3}{|l|}{ Area } \\
\hline Area $(1=$ urban, $2=$ rural $)$ & $\begin{array}{l}1.020 \\
(1.63)\end{array}$ & $\begin{array}{l}0.145 \\
(0.99)\end{array}$ \\
\hline Constant & $\begin{array}{c}-46.435 \\
(-19.70)^{* *}\end{array}$ & $\begin{array}{c}-1.542 \\
(-3.67)^{* *}\end{array}$ \\
\hline Log likelihood & -84.12 & -927.50 \\
\hline
\end{tabular}

* $\quad$ Significant at the 0.05 level.

** $\quad$ Significant at the 0.01 level.

Notes: $\mathrm{N}=1568$ households. Numbers in parentheses are t-statistics (two-tailed). In column (1) the dependent variable is 1 if household receives international remittances and is in the lowest decile group (excluding remittances), and zero otherwise. In column (2), the dependent variable is 1 if household receives international remittances and is not in the lowest decile group (excluding remittances), and zero otherwise. Seven regional and eight ethnic dummy variables are included in the equation, but not reported in the table. 
Figure 1: Lorenz Concentration Curves for Non-Remittance and Remittance-Receiving Households, Guatemala, 2000

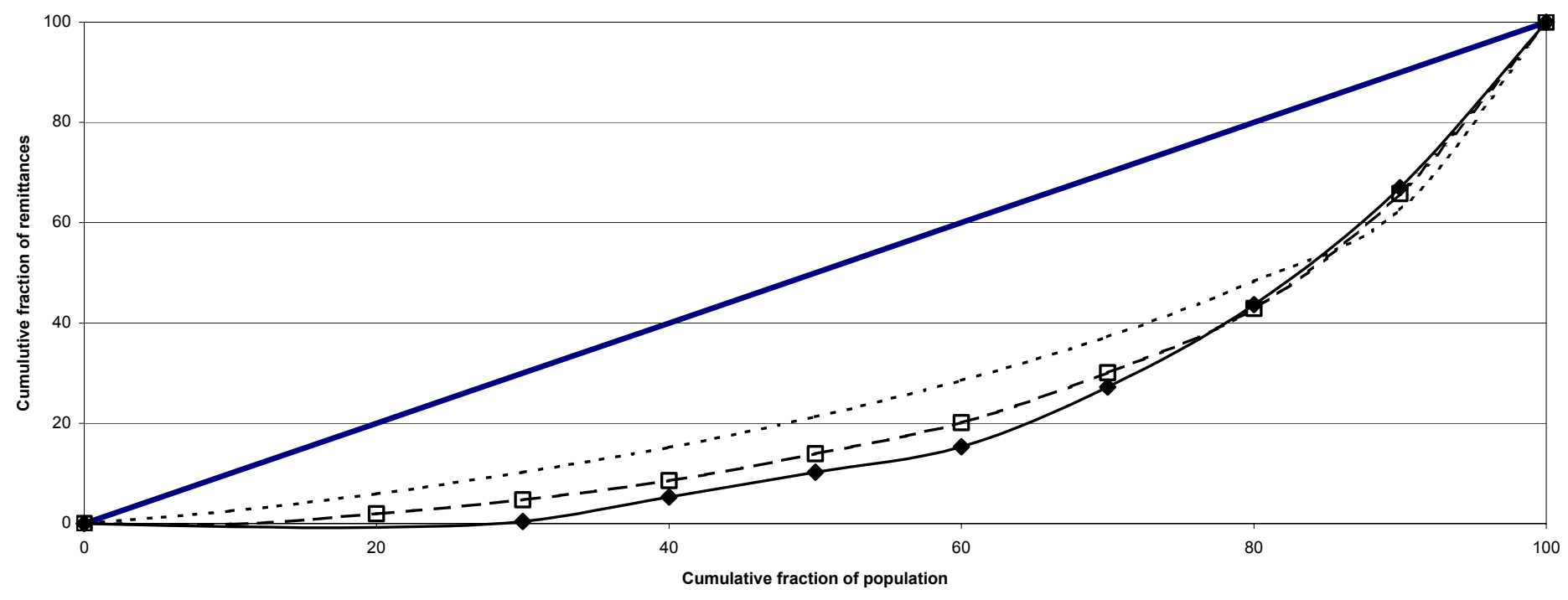

$\longrightarrow$ Line of Perfect Equality - . - Excluding remittances $-\bullet-$ Including Internal remittances $\longrightarrow$ Including International remittances 


\section{Appendix A: Checking the Robustness of Findings Using Observed Expenditure}

\section{Data}

The purpose of this appendix is to see if the poverty and inequality findings of Tables 4 and 5 of this paper are robust for different ways of defining household income (expenditure). Therefore, in this appendix all of the calculations are based on observed - rather than predicted data. In other words, all calculations in this section are based on observed per capita household expenditures, and the income contribution of the migrant in the excluding remittances situation is assumed to be zero.

Using the observed data on per capita household expenditures, Appendix Table 1 replicates Table 4 in the text. All of the main results are as before. For example, the three poverty measures in Appendix Table 1 show that the inclusion of remittances - either internal or international - in household expenditure reduces the level, depth and severity of poverty in Guatemala. However, just as in Table 4, the size of the poverty reduction is greater when measured by indicators focusing on the depth and severity of poverty, such as the squared poverty gap. For instance, while the poverty headcount shows that the inclusion of international remittances in observed household expenditure reduces the level of poverty by only 2.3 percent, the squared poverty gap shows that the inclusion of international remittances reduces the severity of poverty by 13.6 percent. Including remittances - either internal or international -- in observed household expenditure has a greater impact on reducing the severity of poverty in Guatemala than it does on reducing the proportion of people living in poverty.

Appendix Table 1 also reveals that the inclusion of internal or international remittances in observed household expenditure has little impact on income inequality, as measured by the Gini 
coefficient. With the receipt of either internal or international remittances, inequality remains relatively stable with a Gini coefficient of about 0.48 . This finding is identical to that recorded in Table 4 in the main text.

Using the observed data on per capita household expenditure, Appendix Table 2 replicates Table 5 in the text in order to examine what kinds of income (expenditure) groups of households receive remittances. Again, all of the main results are as before. Columns (1) and (3) of Appendix Table 2 show that rich households - specifically, those in the eight and ninth deciles of the expenditure distribution - account for the largest share of remittance-receivers. However, just as before, a surprisingly large share of households receiving remittances -9.7 and 15.2 percent, respectively, for internal and international remittances - are found in the lowest decile group. Moreover, columns (2) and (3) in Appendix Table 2 show that households in the bottom decile group receive a huge share of their total per capita household expenditure (income) from remittances. On average, households in the lowest decile group receiving internal remittances receive 70 percent of their total household income from remittances; households in the bottom group receiving international remittances receive 80 percent of their total household income from this source. This serves to explain why remittances have more of an impact on reducing the severity rather than the level of poverty in Guatemala. When households in the lowest decile group receive internal or international remittances their observed income (expenditure) increases substantially and this has a huge effect on any poverty measure - like the squared poverty gap - which considers the number, distance and distribution of poor households beneath the poverty line 
Appendix Table 1. Effect of Remittances on Poverty for Non-Remittance and Remittance-Receiving Households, Guatemala, 2000

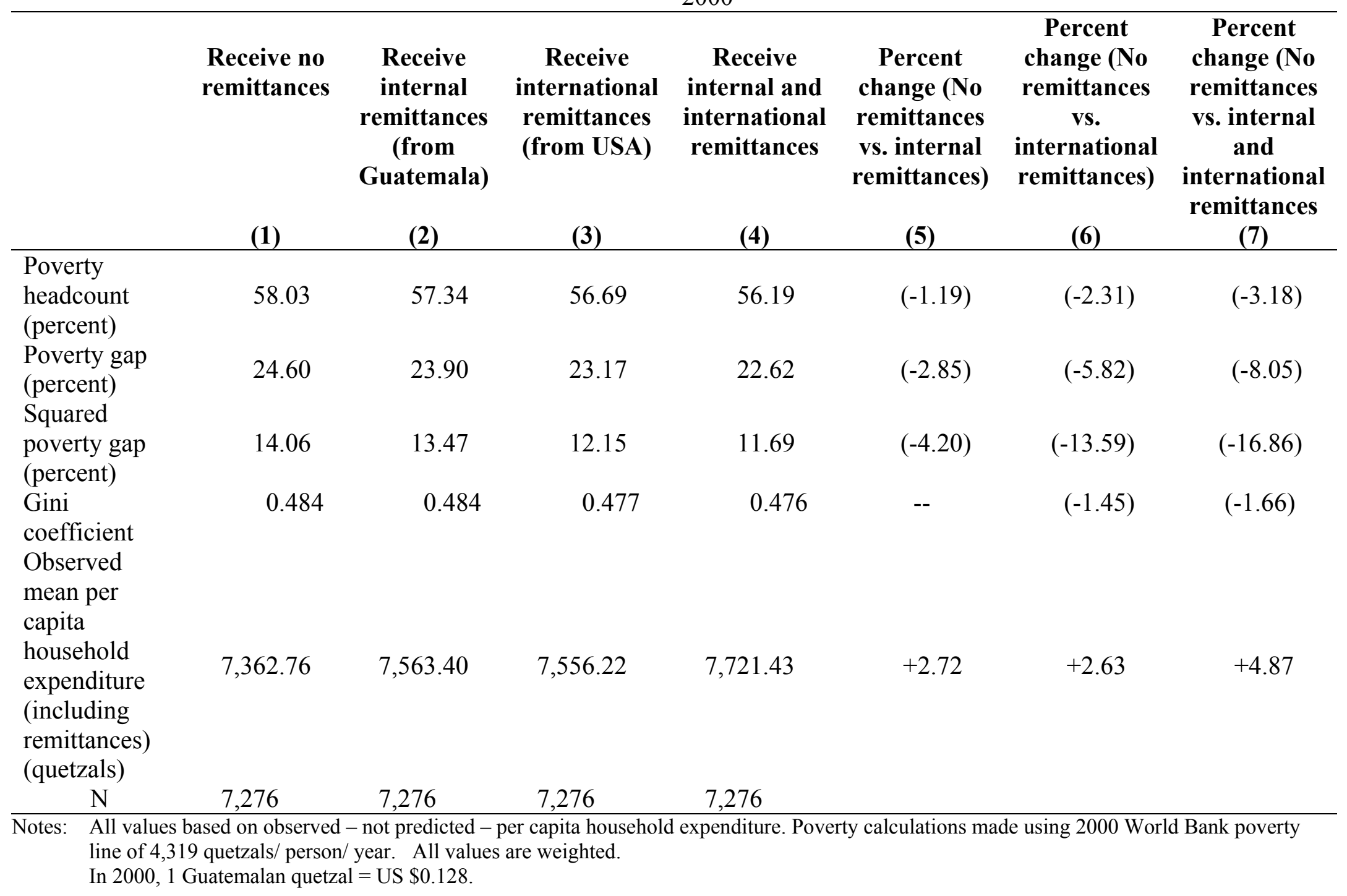

Source: Calculated from Guatemala 2000 ENCOVI Survey 
Appendix Table 2. Distribution of Remittance-Receiving Households by Decile Group, Ranked by Observed Per Capita Household Expenditure, Excluding Remittances

\begin{tabular}{|c|c|c|c|}
\hline Rank & $\begin{array}{l}\text { Households } \\
\text { receiving } \\
\text { internal } \\
\text { remittances } \\
\text { (from } \\
\text { Guatemala) }\end{array}$ & $\begin{array}{c}\text { Internal } \\
\text { remittances as } \\
\text { percent of total } \\
\text { per capita } \\
\text { household } \\
\text { expenditure } \\
\text { (including } \\
\text { remittances) }\end{array}$ & $\begin{array}{l}\text { Households } \\
\text { receiving } \\
\text { international } \\
\text { remittances } \\
\text { (from USA) }\end{array}$ \\
\hline
\end{tabular}

International
remittances as
percent of total
per capita
household
expenditure
(including
remittances)

(1)

(2)

(3)

(4)

(decile)

(percent)

(percent)

(percent)

(percent)

Lowest 10

9.7

70.5

15.2

80.5

Second 10

9.0

33.5

8.1

46.3

Third 10

8.8

12.8

8.6

32.7

Fourth 10

8.7

21.3

6.8

43.1

Fifth 10

9.0

14.0

7.4

21.3

Sixth 10

8.6

15.1

9.8

21.4

Seventh 10

10.4

13.2

9.2

18.4

Eighth 10

14.1

9.1

13.7

18.4

Ninth 10

12.1

19.5

12.2

13.3

Top 10

9.6

10.7

9.0

11.5

100.0

100.0

Notes: All values based on observed - not predicted - data. Households ranked into decile groups on the basis of observed per capita household expenditure (excluding remittances). For those households receiving internal remittances (from Guatemala), column (2) shows the percent of total per capita household expenditure (including remittances) coming from internal remittances. For those households receiving international remittances (from USA), column (4) shows the percent of total per capita household expenditure (including remittances) coming from international remittances.

Source: Calculated from Guatemala 2000 ENCOVI Survey. 
RAdams

$\mathrm{L}: \backslash \mathrm{ADAMS} \backslash$ Guatemala. pov paper combine. doc.doc

September 24, 2004 1:41 PM

${ }^{1}$ While no estimates are available regarding the size of internal remittances, Ratha (2004) has recently estimated that official international remittances to the developing world now total $\$ 93$ billion per year, making them the second most important source of external funding in developing countries.

${ }^{2}$ For estimates of the economic costs of international migration, see Stahl (1982) and Adams (1991, 1998).

${ }^{3}$ While Stark, Taylor and Yitzhaki (1986) and Adams (1992, 1995) examine the impact of internal and international remittances on income inequality in Mexico and Pakistan, respectively, they do not analyze the effect of these financial transfers on poverty.

${ }^{4}$ This 2000 Guatemala household survey was implemented as part of the "Program for the Improvement of Surveys and Measurement of Living Conditions in Latin America and the Caribbean" (ENCOVI), which was sponsored by the Inter-American Development Bank (IDB), the World Bank and the Economic Committee for Latin America and the Caribbean (CEPAL).

${ }^{5}$ For more details on this 2000 Guatemala ENCOVI household survey, see World Bank (2004).

${ }^{6}$ The five possible responses to this "where do these people sending (your household) remittances live" question were: (1) Guatemala; (2) United States; (3) Mexico; (4) Central America; and (5) other countries.

${ }^{7}$ As explained on page 8, the focus here is on predicting per capita household expenditure (excluding remittances), rather than income. See page 8 of text.

${ }^{8}$ This method of predicting incomes (expenditures) assumes that the only way in which households receiving no remittances differ from households receiving internal and international remittances is that the latter group of households receive remittances. Non-remittance receiving and remittance receiving households are not assumed to differ in any entrepreneurial or other way which might affect their expenditure in a manner apart from the relationships captured by the variables used in the predicted income equations.

${ }^{9}$ Results are similar when equation (2) is estimated by a log-linear model.

10 The expenditure variable in this data set is quite comprehensive and includes household expenditures on the following categories of goods: food (purchased and home produced), consumer goods, household services (energy, water), housing (annual use value), durable goods, education, health, transport and communication.

${ }^{11}$ For more information on this expenditure-based poverty line for Guatemala, see page 12 of text.

${ }^{12}$ For more on the life-cycle effects of household expenditure, see Deaton $(1992,1997)$.

${ }^{13}$ See, for example, Psacharopoulos $(1985,1994)$ and Glewwe and Jacoby (2004). 
${ }^{14}$ While international remittances are (on average) about 58 percent larger than internal remittances, it should be noted that about twice as many households receive internal remittances (1063 households) as opposed to international remittances (593 households).

${ }^{15}$ According to the World Bank, this is a "full" poverty line because it includes both food and nonfood expenditure. For more details on how the World Bank calculated this expenditure-based poverty line for Guatemala, see World Bank (2004: Annex 3).

${ }^{16}$ The poverty and inequality results in Table 4 are based on including remittances - internal or international - in predicted per capita household expenditure. However, as shown in Appendix A, the poverty and inequality results are similar when remittances are included in observed - rather than predicted -- per capita household expenditure. See Appendix A and Appendix Tables 1 and 2.

${ }^{17}$ These results are different from those reported by Adams (1995) for rural Pakistan, where internal remittances were found to reduce income inequality, and international remittances represented an inequality-increasing source of income.

${ }^{18}$ Since the decile rankings in Table 5 are based on per capita household expenditure (excluding remittances), the findings in this table may appear to differ from those of Table 4 and Figure 1, where the ranking of households is based on per capita household expenditures (including remittances). As noted in the text, households receiving internal or international remittances make considerable changes in their decile rankings between the excluding and including remittances situations.

${ }^{19}$ One possible reason for the disappointing logit results in Table 7 is the limited number of households (49) in the lowest decile group that are receiving international remittances. 


\section{$\underline{\text { References }}$}

Adams, Jr., Richard. 1991. The Effects of International Remittances on Poverty, Inequality and Development in Rural Egypt. Research Report 86. International Food Policy Research Institute, Washington, DC.

Adams, Jr., Richard. 1992. "The Effects of Migration and Remittances on Inequality in Rural Pakistan." Pakistan Development Review, 31, 110-133.

Adams, Jr., Richard. 1995. Sources of Income Inequality and Poverty in Rural Pakistan. Research Report 102. International Food Policy Research Institute, Washington, DC.

Adams, Jr., Richard. 1998. "Remittances, Investment and Rural Asset Accumulation in Pakistan." Economic Development and Cultural Change, 47, 155-173.

Deaton, Angus. 1992. Understanding Consumption. Oxford: Clarendon Press.

Deaton, Angus. 1997. The Analysis of Household Surveys: A Microeconomic Approach to Development Policy. Baltimore: Johns Hopkins Press.

Glewwe, Paul and Jacoby, Hanan. 2004. "Economic Growth and the Demand for Education: Is There a Wealth Effect." Journal of Development Economics, 74, 33-51.

Psacharopoulos, George. 1985. "Returns to Education: A Further International Update and Implications." Journal of Human Resources, 20, 583-604.

Psacharopoulos, George. 1994. "Returns to Investment in Education: A Global Update.” World Development, 22, 1325-1343.

Ratha, Dilip. 2004. "Enhancing the Developmental Effect of Workers' Remittances to Developing Countries.” In World Bank, Global Development Finance, pp. 169-173. Washington, DC.

Stahl, Charles. 1982. "Labor Emigration and Economic Development." International Migration Review, $16,868-899$.

Stark, Oded. 1991. The Migration of Labor. Cambridge, MA: Harvard University Press.

Stark, Oded, Taylor, J. Edward and Yitzhaki, Shlomo. 1986. "Remittances and Inequality." The Economic Journal, 96, 722-740.

World Bank. 2004. Poverty in Guatemala. Washington, DC. 
World Bank. 2004. Global Development Finance. Washington, DC. 